ORIGINAL

\title{
Comparison of systemic and intramammary dry cow treatments
}

\section{Comparación de terapias sistémicas e intramamarias para el periodo seco en vacas lecheras}

\author{
G. Andres Contreras B, ${ }^{1 *}$ Ph.D, Walter M. Guterbock, ${ }^{2}$ M.Sc, Juan Muñoz R, ${ }^{1}$ Ing. Agr, \\ Phillip M. Sears, ${ }^{1}$ Ph.D.
}

\begin{abstract}
${ }^{1}$ Michigan State University, College of Veterinary Medicine Department of Large Animal Clinical Sciences, East Lansing, Michigan, USA. ${ }^{2}$ denDulk Dairy, Coopersville, Michigan, USA. *Correspondencia:contrera@ crm.msu.edu
\end{abstract}

Recibido: Abril de 2011; Aceptado: Mayo de 2012.

\begin{abstract}
Objective. To compare four different dry cow treatments (DCT) and establish their effectiveness in reducing intramammary infections (IIM). Materials and methods. DCTs included systemic tylosin $(12 \mathrm{~g})$ alone or accompanied by cefapirine intramammary infusions and or an internal teat sealant. A total number of 278 cows at the end of lactation period were randomly assigned to one of 4 dry cow treatment groups: CESE Group $(n=89)$, intramammary cephapirin and teat sealant. TYCESE Group $(n=84)$, intramammary cephapirin, tylosin $12 \mathrm{~g}$ intramuscular and teat sealant. TYSE Group $(n=86)$, $12 \mathrm{~g}$ intramuscular tylosin and teat sealant; TY Group $(\mathrm{n}=76) 12 \mathrm{~g}$ intramuscular tylosin only. Milk samples for culture were collected at dry-off and 1 and 2 weeks after calving. Somatic cell counts (SCC) were taken from Dairy Herd Improvement Association (DHI) tests at dry-off, and the first two test days after calving. Results. Bacteria cure rate for Gram-positive intramammary infections (IMI) for TYCESE group was $93.6 \%$, CESE group $78.9 \%$, TYSE group $88.2 \%$, and TY group $78.1 \%$. All four groups showed a decrease in the SCC upon the first and second test after calving. Conclusions. The use of systemic tylosin in combination with intramammary antibiotics increased DCT effectiveness improving the Gram-positive cure rate IMI. Furthermore, systemic tylosin alone plus teat sealant is as effective as cephapirin plus teat sealant when used as DCT.
\end{abstract}

Key words: Dry period, mastitis, tylosin (Source: $C A B$ ).

\section{RESUMEN}

Objetivo. Comparar 4 tratamientos para el periodo seco (TPS) y establecer su efectividad en reducir infecciones intramamarias (IIM). Materiales y métodos. Los TPS incluían tilosina sistémica (12 g) solamente o acompañada con infusiones intramamarias de cefapirina y/o un sellante interno de pezones. Un total de 278 vacas al final de la lactancia fueron asignadas al azar a 1 de 4 grupos de tratamiento. Grupo CESE $(n=89)$, cefapirina y sellante interno de pezones. Gupo TYCESE $(n=84)$, cephapirina intramamaria, tilosina intramuscular y sellador interno de pezones. Grupo TYSE $(n=86)$, tilosina intramuscular y sellante interno de pezones. Grupo TY $(n=76)$ tilosina intramuscular solamente. 
Muestras de leche de cada cuarto productivo fueron tomadas al momento del secado, y 1 y 2 semanas después del parto. Los recuentos individuales de células somáticas (RCS) fueron tomados del control lechero (DHI) en sus pruebas de antes del momento de secado, y las primeras dos pruebas después del parto. Resultados. Las tasa de cura bacteriológica para IIM causadas por Gram positivos en TYCESE fue de $93.6 \%$, para CESE $78.9 \%$, TYSE $88.2 \%$ y TY $78.1 \%$. Todos los grupos de tratamiento mostraron una disminución en RCS a la primera y segunda prueba despues del parto en comparación con la de secado. Conclusiones. El uso de tilosina en combinación con cefapirina incremento la efectividad del TPS, mejorando las tasas de cura de IIM por Gram positivos. Además TYSE fue tan efectivo como CESE en la reducción de IIM.

Palabras Clave: Mastitis, periodo seco, tilosina (Fuente: $C A B$ ).

\section{INTRODUCTION}

Dry cow therapy (DCT) is defined as the use of antibiotics immediately after the last milking of lactation. There are three different approaches to DCT. First, intramammary dry treatment alone is widely used and very effective in reducing intramammary infections (IMI) $(1,2)$. However, low efficacy against some coagulase negative staphylococci (CNS) IMI has been demonstrated. (3) Another approach is systemic dry cow therapy, which is relatively inexpensive and easy to use but has been reported to be less effective.

For example, Nickerson et al (4) administered tilmicosin subcutaneously and found it to be less effective against IMI caused by Staphylococcus aureus than intramammary infusions of cephapirin or tilmicosin. Finally a combination of systemic and intramammary antibiotics can also be administered. However, its efficacy depends upon the antibiotic class pharmacological characteristics. In fact, Erskine et al (5) reported a low efficacy against Staphylococcus aureus IMI when using oxytetracycline hydrochloride systemically in combination with intramammary cephapirin benzathine. The low efficacy of this treatment could have been related to the poor diffusion of oxytetracycline into the mammary gland.

The use of tylosin as systemic DCT was reported to be as effective as intramammary infusion with a preparation with beta lactams and streptomycin against CNS (6). However, combined DCT including systemic tylosin has not been previously reported. This antibiotic belongs to the macrolide family of antibiotics. One of the main advantages of this type of antimicrobials is an excellent diffusion into the mammary gland related to its basic $\mathrm{pK}(\mathrm{pH}$ at which concentrations of dissociated and undissociated antibiotic are equal), which results in a very high milk to plasma concentration ratio of $5: 1$ $(7,8)$. Once the macrolides are in milk they are virtually trapped inside the mammary gland.
The objective of this study was to compare four different DCTs and establish the effectiveness of systemic (intramuscular) tylosin therapy as DCT at quarter level when was added to intramammary infusion of cephapirin, a teat sealant, or alone as systemic DCT.

\section{MATERIALS AND METHODS}

Study site. Cows on a large commercial farm in Michigan were selected. Every week, for two months, and after confirming their gestation to be greater than 150 days, a group of Holstein cows in their second, third or fourth lactation due to go dry were assigned to one of four DCT groups. A completely randomized design that included three treatments and a control was used (Table 1).

Table 1. Summary of gram-positive intramammary infections by treatment groups at cow and quarter level.

\begin{tabular}{|c|c|c|c|c|}
\hline & \multicolumn{4}{|c|}{ Treatment $^{1}$} \\
\hline & CESE & TYCESE & TYSE & TY \\
\hline Cows Enrolled & 75 & 71 & 72 & 60 \\
\hline $\begin{array}{l}\text { Cows with IMI at dry-off } \\
\text { (\% cows infected) }\end{array}$ & $\begin{array}{c}30 \\
(40 \%)\end{array}$ & $\begin{array}{c}28 \\
(39 \%)\end{array}$ & $\begin{array}{c}33 \\
(45 \%)\end{array}$ & $\begin{array}{c}32 \\
(53 \%)\end{array}$ \\
\hline $\begin{array}{l}\text { Cow cured after DCT } \\
\text { (\% cows cured) }\end{array}$ & $\begin{array}{c}20 \\
(66 \%)^{\mathrm{ab}}\end{array}$ & $\begin{array}{c}21 \\
(75 \%)^{a}\end{array}$ & $\begin{array}{c}17 \\
(51 \%)^{\mathrm{ab}}\end{array}$ & $\begin{array}{c}15 \\
(46 \%)^{b}\end{array}$ \\
\hline $\begin{array}{l}\text { Cows with new IMI } \\
\text { after calving }\end{array}$ & 4 & 4 & 6 & 5 \\
\hline Quarters Enrolled & 289 & 271 & 276 & 226 \\
\hline Non-functional quarters & 11 & 13 & 12 & 14 \\
\hline $\begin{array}{l}\text { Quarters infected at } \\
\text { dry-off ( } \% \text { quarters } \\
\text { infected) }\end{array}$ & $\begin{array}{c}57 \\
(19.7 \%)^{\mathrm{b}}\end{array}$ & $\begin{array}{c}47 \\
(17.3 \%)^{\mathrm{b}}\end{array}$ & $\begin{array}{c}68 \\
(24.6 \%)^{a}\end{array}$ & $\begin{array}{c}73 \\
(32.3 \%)^{a}\end{array}$ \\
\hline $\begin{array}{l}\text { Quarters cured after } \\
\text { DCT }(\% \text { quarters cured) }\end{array}$ & $\begin{array}{c}45 \\
(78.9 \%)^{\mathrm{b}}\end{array}$ & $\begin{array}{c}44 \\
(93.6 \%)^{\mathrm{a}}\end{array}$ & $\begin{array}{c}60 \\
(88.2 \%)^{\mathrm{a}}\end{array}$ & $\begin{array}{c}57 \\
(78.1 \%)^{\mathrm{b}}\end{array}$ \\
\hline
\end{tabular}

${ }^{1}$ Treatment designations: CESE cephapirin $300 \mathrm{mg}$ intramammary and Orbeseal ${ }^{\circledR}$ (4 g of internal teat sealant containing $65 \%$ bismuth subnitrate); TYCESE: tylosin $12 \mathrm{~g}$ intramuscular, cephapirin $300 \mathrm{mg}$ intramammary, and Orbeseal ${ }^{\circledR}$; TYSE: Tylosin $12 \mathrm{~g}$ intramuscular and

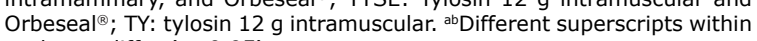
each row differ $(p<0.05)$. 
Treatments. Treatment CESE ( $n=89$ cows), reflecting standard practice on the farm, was used as control. After the last milking of lactation, animals were first infused in each productive quarter with a commercial preparation of $300 \mathrm{mg}$ of cephapirin (Tomorrow ${ }^{\circledR}$, Fort Dodge, Ft Dodge, Iowa, USA) intramammary and then with $4 \mathrm{~g}$ of commercially available internal teat sealant containing $65 \%$ bismuth subnitrate (Orbeseal ${ }^{\circledR}$, Pfizer. New York, New York, USA). Treatment TYCESE ( $n=84$ cows) animals were first infused in each productive quarter with cephapirin intramamary 300 $\mathrm{mg}$, then injected intramuscularly with tylosin (Tylosin, Agripharma. Westlake, Texas, USA) $12 \mathrm{~g}$ and finally were infused with teat sealant. Group TYSE ( $n=86$ cows) animals received tylosin $12 \mathrm{~g}$ intramuscular and then teat sealant was infused in each productive quarter. Group TY ( $n=76$ cows) animals received $12 \mathrm{~g}$ tylosin intramuscularly. Intramammary infusions were administered by the partial insertion technique.

Prior to instillation. All teat ends were prepared following the farm's milking preparation routine that included a predip solution containing $0.1 \%$ iodine, after which the dry teat end was disinfected with a cotton pad containing $70 \%$ isopropyl alcohol. Intramuscular injections were given in the neck, splitting the dose between two different sites. Tylosin dosage calculation was based in $20 \mathrm{mg} / \mathrm{Kg}$ dose for a $600 \mathrm{Kg}$ cow (average weight for mature cows on this commercial farm).

Milk samples. Quarter milk samples were taken following National Mastitis Council guidelines (9) from all functional quarters at dry-off and at 1 and 2 wks after calving. Samples were immediately processed at the dairy's on-farm laboratory. A $10 \mu \mathrm{L}$ aliquot from each sample was cultured on blood agar containing $0.5 \%$ esculin at $37^{\circ} \mathrm{C}$ for $24 \mathrm{~h}$. Colonies were tentatively identified as CNS, streptococci, Staphylococcus aureus, coliforms or others; a presumptive diagnosis of CNS, streptococci, coliform, or other pathogens was made, based on colony growth, morphology and appearance, pattern of hemolysis, and catalase reaction. Staphylococcal isolates were tested for coagulase production with the tube coagulase test. Gram-negative bacteria were plated on MacConkey agar to facilitate identification. Only CNS, streptococci and S. aureus were included in data analysis.

This approach was based on the label use for cephapirin $\left(\right.$ Tomorrow $^{\circledR}$ ) and Tylosin sold in the United States at the time of the trial, not on their antibacterial activity. A cow was considered infected if at least one productive quarter had an
IMI. A quarter was considered infected if five or more cfu of the same kind were identified, and was considered contaminated if three or more different colony types were present. Post calving samples were used to establish bacterial cure. A cow was considered cured if she had an IMI at dry-off and all productive quarters were negative at both samples post-calving. A cow was not cured if she had an IMI at dry-off and continued with the same quarter(s) infected with the same species at first and second test after calving. A quarter was considered cured if it was positive at dry-off and negative in first and second postcalving samples. It was considered not cured if it was positive to the species found at dry-off and again 1 and/or 2 wk after calving. A quarter was considered newly infected if it was negative at dry-off and positive at 1 and 2 wk after calving Dairy Herd Improvement (DHI) tests were recorded to monitor SCC.

The last test of lactation was considered the drytest, and then linear SCC scores from subsequent monthly tests, were used to determine changes in SCC. Milk production records were collected by $\mathrm{DHI}$ personnel and total production was established as projected to 305 days mature equivalent (ME) by a herd management software (DairyComp ${ }^{\circledR}$, Herd Management software, Valley Agricultural Software, Tulare, California, USA) based on milk production at DHI test taken between 180 and 200 days in milk (DIM) after calving following the DCT assigned. A composite milk sample was taken at calving to perform antibiotic residue test (Delvotest ${ }^{\circledR}$ system, DMS food specialties, Parsippany, New Jersey, USA). Cows with less than $30 \mathrm{~d}$ dry were excluded because of antimicrobial residue issues that required milk withdrawal. Cows with more than $100 \mathrm{~d}$ dry were also excluded. Of the 335 cows enrolled in the dry cow treatment trial, 278 had complete records and were included in the results.

Analysis of results. Culture results were analyzed with the PROC GLIMMIX procedure for binary variables (SAS Inst. Inc., Cary, North Carolina, USA). Results were blocked by sampling date and the random statement was assigned to quarter within cow as experimental unit. The SCC scores were analyzed as repeated measures using a mixed model procedure (PROC MIXED; SAS Inst. Inc., Cary, North Carolina, USA) following the equation:

$Y_{i j k}=\mu+G_{i j}$
$S_{k} * G_{i} * I_{j}+E_{i j k}$ Where $Y_{i j k}$ is the dependent variable SCC score for a cow in group $i$, with infection status $j$, at 
sample $\mathrm{k}$ as repeated measure, and $\mathrm{E}_{\mathrm{ijk}}$ is the random error assumed to be correlated. The Satterthwaite's method for estimating degrees of freedom was used. Significance level was set at alpha $=0.05$.

\section{RESULTS}

A total of 123 cows (44\%) had IMI at dry-off and no differences in infection rate were found when comparing all four groups. Percentages of cows with IMI within each treatment group were as follows CESE 40\%, TYCESE 39\%, TYSE $45 \%$ and TY 53\%. Cure rates at cow level were significantly higher for group TYCESE (75\%) when compared to group TY (46\%). Group CESE had a $(66 \%)$ cure rate and TYSE $(51 \%)$ and this difference was not significant. A summary of these results is shown in table 1 . Despite of the use of antibiotics, residue tests were negative on all samples taken after calving.

A total of 245 quarters ( $23 \%$ overall) were found infected with CNS, streptococci or S. aureus. IMI rates by quarters at dry-off are shown in table 1. Group TY had $32.3 \%$ infected quarters and group TYSE had $24.6 \%$, both were significantly higher $(p<0.05)$ than TYCESE $17.3 \%$ and CESE $19.7 \%$. Gram-positive bacterial infection results are summarized in table 2.

Table 2. Summary of gram-positive culture results by treatment groups at quarter level.

\begin{tabular}{lcccc}
\hline & \multicolumn{4}{c}{ Treatment ${ }^{1}$} \\
\cline { 2 - 5 } & CESE & TYCESE & TYSE & TY \\
\hline $\begin{array}{lcccc}\text { CNS }^{2} \text { quarters infected at dry- } \\
\text { off (\% quarters infected) }\end{array}$ & 41 & 27 & 28 & 58 \\
$(72 \%) \mathrm{a}$ & $(57 \%) \mathrm{b}$ & $(41 \%) \mathrm{b}$ & $(79 \%) \mathrm{a}$ \\
CNS \% quarters cured after & $73 \% \mathrm{a}$ & $92 \% \mathrm{~b}$ & $89 \% \mathrm{~b}$ & $72 \% \mathrm{a}$ \\
DCT & 14 & 18 & 34 & 14 \\
$\begin{array}{l}\text { Streptococci quarters infected } \\
\text { at dry-off (\% quarters infected) }\end{array}$ & $(24 \%)$ & $(38 \%)$ & $(50 \%)$ & $(19 \%)$ \\
$\begin{array}{l}\text { Streptococci quarters cured } \\
\text { after DCT }\end{array}$ & $100 \%$ & $94 \%$ & $91 \%$ & $100 \%$ \\
$\begin{array}{l}\text { S aureus quarters infected at } \\
\text { dry-off }\end{array}$ & 2 & 2 & 6 & 1 \\
\hline
\end{tabular}

${ }^{1}$ Treatment designations: CESE cephapirin $300 \mathrm{mg}$ intramammary and Orbeseal ${ }^{\circledR}$ ( $4 \mathrm{~g}$ of internal teat sealant containing $65 \%$ bismuth subnitrate); TYCESE: tylosin $12 \mathrm{~g}$ intramuscular, cephapirin $300 \mathrm{mg}$ intramammary, and Orbeseal ${ }^{\circledR}$; TYSE: Tylosin $12 \mathrm{~g}$ intramuscular and Orbeseal ${ }^{\circledR}$; TY: tylosin $12 \mathrm{~g}$ intramuscular.

${ }^{2} \mathrm{CNS}=$ coagulase negative staphylococci

ab Different superscripts within each row differ $(p<0.05)$.

CNS accounted for $62.9 \%$ of the infections, streptococci for $32.6 \%$ and $S$. aureus for $4.5 \%$. The staphylococcal infection rate was significantly higher in group TY when compared to TYCESE and TYSE $(p<0.05)$ (Table 1$)$. Infections caused by $S$ aureus were found in 2 quarters of group CESE, 2 quarters of TYCESE, 6 quarters of TYSE and 1 quarter of TY. With such a small number of infections it was not possible to establish differences among groups. Furthermore, IMI with $\mathrm{S}$ aureus exhibit intermittent shedding that requires at least 3 multiple samplings to identify a truly infected quarter and this trial only collected 1 sample at dry-off (10). Further studies are needed to evaluate tylosin efficacy alone or in combination with other antibiotics and or teat sealants against $S$. aureus IMI. Coliform infections were found in 5 quarters from 3 different cows at the moment of dry-of (results not shown). These infections were cleared after parturition.

Bacterial cure rates for gram-positive bacteria by quarters are shown in table 2. TYCESE had the highest cure rate $(93.6 \%)$ and was significantly different $(p<0.05)$ from TY $(78.1 \%)$ and CESE (78.9\%). No difference was found when TYCESE was compared to Group TYSE (88.2\%). New infections rates were low, group CESE (1.8\%), group TYCESE (2.6\%), group TYSE (2.9\%) and group TY (3.3\%). When comparing cure rates by bacteria type (Table 1) all four treatments had good efficacy against streptococcal infections, but there were differences in cure rates for staphylococcal infections. Group TYCESE had higher cure rates (92.5\%) than CESE (73.17\%) and TY (72.4\%) $(p<0.05)$.

All four treatments resulted in a decrease in the SCC at the first and second test after calving and no statistical differences were observed among them (Figure 1). Milk production at test date between 180 to 200 DIM was analyzed using 305 ME value. Milk production for each treatment group was as follows: TYCESE $23.910 \pm 5.686 \mathrm{lb}$, CESE 22.056 $55.104 \mathrm{lb}$, TY $21.900 \pm 4.278 \mathrm{lb}$ and TYSE $21.791 \pm 4.086 \mathrm{lb}$. When the difference between arithmetic mean of previous and current lactations was calculated for all groups, no significant differences were found.

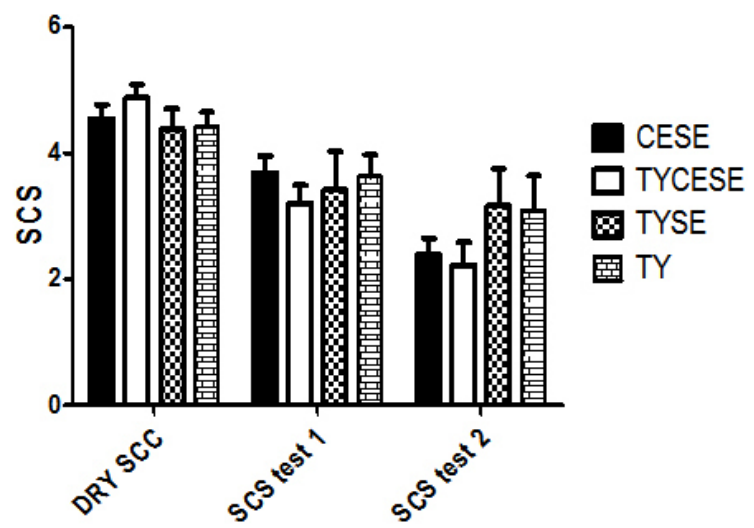

Figure 1. logSCC at dry-off, first test and second test after calving for each treatment group. Values are means \pm SEM. 


\section{DISCUSSION}

Bacterial cure rates for systemic tylosin (group TY $78.1 \%$ ) are similar to those obtained by McDougall et al (11) in New Zealand, who administered tylosin intramuscularly to treat clinical mastitis during lactation and obtained $82 \%$ cure rates for Gram-positive infections. Systemic tylosin as DCT alone (TY) or plus teat sealant (TYSE) is as effective as intramammary cephapirin plus teat sealant (Group CESE $78.9 \%$ ) to reduce IMI.

The randomization was effective in distributing IMI among groups at cow level, but was ineffective at quarter level generating a bias, observed in a higher number of quarter infections and a lower cure rate for the TY group. An ideal randomization would have included blocking after culturing quarters but this process would have represented major logistical problems on this commercial farm. However, all four DCTs were effective in reducing IMI.

Nickerson et al (4) used a systemic macrolide (tylmicosin) to treat IMI during the dry period reporting low cure rates against staphylococcal infections, however, the dose $(1 \mathrm{mg} / \mathrm{Kg})$ used by the authors does not have bacteriocidal activity, and subcutaneous administration could have delayed antibiotic distribution. Tylosin's effectiveness during this trial could be related to its distribution properties and the fact that a higher than recommended dose with a single injection was used. Tylosin's peak milk concentration was reported to be $10 \mu \mathrm{g} / \mathrm{ml}$ after a single injection at a dose of $20 \mathrm{mg} / \mathrm{Kg} \mathrm{b.w.} \mathrm{(12)}$ and $18 \mu \mathrm{g} / \mathrm{ml}$ after three repeated injections at a dose of $10 \mathrm{mg} / \mathrm{Kg} \mathrm{b.w} \mathrm{(13).}$

In the present work, tylosin's dose was based on average calving weight for cows $(600 \mathrm{Kg})$ at 20 $\mathrm{mg} / \mathrm{Kg}$. Despite of the relative high dose used, antibiotic residues were not found in the composite samples taken at calving. It is presumable that peak milk concentration in tylosin treated animals was higher than previously reported, therefore achieving bactericidal activity, which was observed for macrolides when used in high concentrations (14).

When analyzing cure rate by bacteria type, intramammary treatment alone could have been limited in its ability to eliminate infections during the dry period (CESE 73.2\%). Similar to what was reported by Bolurchi et al (6) inclusion of systemic tylosin in DCT increased cure rates for CNS IMI. Because CNS could be responsible of nearly half of the IMI during the dry period, an increase in the cure rate towards this bacteria type obtained by the addition of systemic tylosin to the intramammary DCT would have an important economic impact (15).

In conclusion, DCT remains a cost-effective measure compared with no treatment at dryoff $(3,16,17)$. The use of systemic tylosin in combination with the intramammary cephapirin increased the effectiveness of intramammary DCT against Gram-positive IMI. Though, inclusion of a combined systemic and intramammary treatment has to be based on an economic analysis of the increased cost of such therapy versus its higher effectiveness. Interestingly, there were no differences between the use of tylosin plus teat sealant and intramammary cephapirin plus teat sealant at dry-off. Therefore the use of these 2 DCT options may be based on the logistical advantages of each treatment protocol. Tylosin may have the advantage of being easier to administer in dairies with confinement housing where headlocks are available to treat large groups of animals. Finally, it is important to mention that adding the teat sealant to the systemic treatment with tylosin at dry-off improved the response of the treatment. Further studies are needed to validate this effect in other dairy herds and to test the use of extended therapy with tylosin particularly when selective DCT is used.

\section{REFERENCES}

1. Berry EA, Hillerton JE. The Effect of Selective Dry Cow Treatment on New Intramammary Infections. J Dairy Sci 2002; 85(1):112-21.

2. Zwald AG, Ruegg PL, Kaneene JB, Warnick LD, Wells SJ, Fossler C, et al. Management Practices and Reported Antimicrobial Usage on Conventional and Organic Dairy Farms. J Dairy Sci 2004; 87(1):191-201.
3. Robert $A$, Seegers $H$, Bereille N. Incidence of intramammary infections during the dry period without or with antibiotic treatment in dairy cows - a quantitative analysis of published data. Vet Res 2006; 37:25-48.

4. Nickerson SC, Owens WE, Fox LK, Scheifinger CC, Shryock TR, Spike TE. Comparison of Tilmicosin and Cephapirin as Therapeutics for Staphylococcus aureus Mastitis at Dryoff. J Dairy Sci 1999; 82(4):696-703. 
5. Erskine RJ, Bartlett PC, Crawshaw PC, Gombas DM. Efficacy of Intramuscular Oxytetracycline as a Dry Cow Treatment for Staphylococcus aureus Mastitis. J Dairy Sci 1994; 77(11):3347-3353.

6. Bolourchi M, Hovareshti P, Tabatabayi AH. Comparison of the effects of local and systemic dry cow therapy for staphylococcal mastitis control. Prev Vet Med 1995; 25(1):63-67.

7. Omura S. Macrolide antibiotics. Macrolide antibiotics, chemistry, biology and practice 1ed. Orlando: Academic press; 1984.

8. Riviere J. Comparative pharmacokinetics: principles, techniques, and applications. Ames: Iowa State University Press; 1999.

9. Hogan J, Gonzalez R, Harmon R, Nickerson SC, Oliver S, Pankey J. Laboratory Handbook on Bovine Mastitis. 1st ed. Madison, WI: The National Mastitis Council, Inc; 1999.

10. Sears PM, Smith BS, English PB, Herer PS, Gonzalez RN. Shedding Pattern of Staphylococcus aureus from Bovine Intramammary Infections. J Dairy Sci 1990; 73(10):2785-2789.

11. McDougall S, Agnew KE, Cursons R, Hou XX, Compton CRW. Parenteral Treatment of Clinical Mastitis with Tylosin Base or Penethamate Hydriodide in Dairy Cattle. J Dairy Sci 2007; 90(2):779-789.
12. Ziv G, Sulman F. Serum and milk concentrations of spectinomycin and tylosin in cows and ewes. Am J Vet Res 1973; 34(3):329-333.

13. el-Sayed $M$, el-Attar $H$, Atef $M$, Yousif $M$. Pharmacokinetic profile of tylosin in mastitic cows. Dtsch Tierarztl Wochenschr 1986; 93(7):326-328.

14. Diarra MS, Malouin F, Jacques M. Postantibiotic and physiological effects of tilmicosin, tylosin, and apramycin at subminimal and suprainhibitory concentrations on some swine and bovine respiratory tract pathogens. Int J Antimicrob Agents 1999; 12(3):229-237.

15. Dingwell RT, Kelton DF, Leslie KE. Management of the dry cow in control of peripartum disease and mastitis. Vet Clin North Am Food Anim Pract 2003; 19(1):235-265.

16. Berry EA, Hogeveen $\mathrm{H}$, Hillerton JE. Decision tree analysis to evaluate dry cow strategies under UK conditions. J Dairy Res 2004; 71(04):409-418.

17. Huijps K, Hogeveen H. Stochastic Modeling to Determine the Economic Effects of Blanket, Selective, and No Dry Cow Therapy. J Dairy Sci 2007; 90(3):1225-1234. 